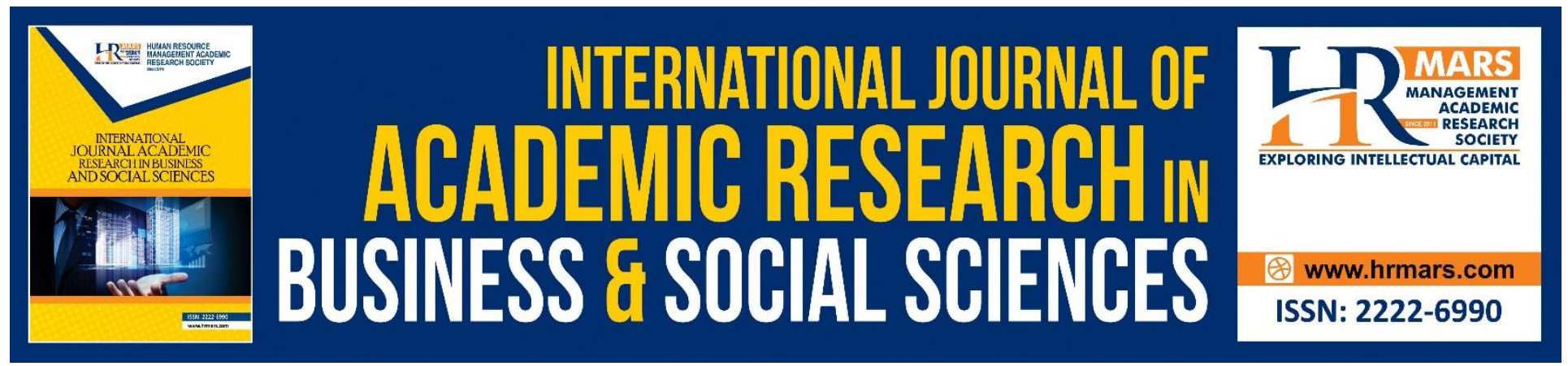

\title{
The Mediating Role of Innovation on Access to Finance and Business Performance of Women Entrepreneurs
}

\author{
Rahmat Magajiya Aliyu, Tunku Salha Binti Tunku Ahmad and Norshahrizan \\ Binti Nordin
}

To Link this Article: http://dx.doi.org/10.6007/IJARBSS/v9-i3/5644

DOI: $\quad 10.6007 /$ IJARBSS/v9-i3/5644

Received: 21 Feb 2019, Revised: 11 March 2019, Accepted: 23 March 2019

Published Online: 29 March 2019

In-Text Citation: (Aliyu, Ahmad, \& Nordin, 2019)

To Cite this Article: Aliyu, R. M., Ahmad, T. S. B. T., \& Nordin, N. B. (2019). The Mediating Role of Innovation on Access to Finance and Business Performance of Women Entrepreneurs. International Journal of Academic Research in Business and Social Sciences, 9(3), 147-159.

\section{Copyright: (C) 2019 The Author(s)}

Published by Human Resource Management Academic Research Society (www.hrmars.com)

This article is published under the Creative Commons Attribution (CC BY 4.0) license. Anyone may reproduce, distribute, translate and create derivative works of this article (for both commercial and non-commercial purposes), subject to full attribution to the original publication and authors. The full terms of this license may be seen

at: http://creativecommons.org/licences/by/4.0/legalcode

Vol. 9, No. 3, 2019, Pg. 147 - 159

http://hrmars.com/index.php/pages/detail/IJARBSS

JOURNAL HOMEPAGE

Full Terms \& Conditions of access and use can be found at http://hrmars.com/index.php/pages/detail/publication-ethics 


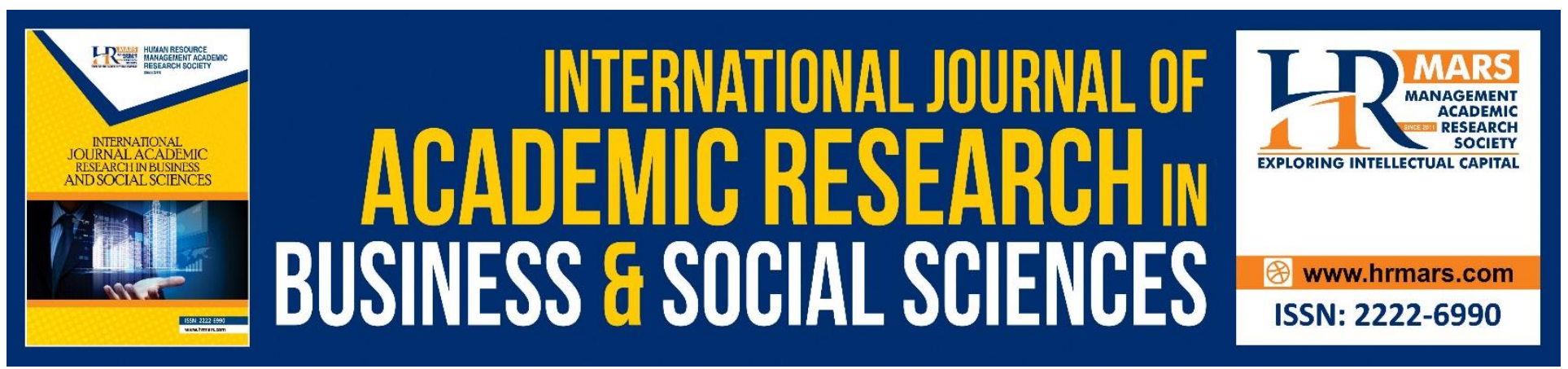

\section{The Mediating Role of Innovation on Access to Finance and Business Performance of Women Entrepreneurs}

\section{Rahmat Magajiya Aliyu, Tunku Salha Binti Tunku Ahmad and Norshahrizan Binti Nordin}

School of Business Innovation and Technopreneurship, Universiti Malaysia Perlis, Kangar, Perlis, Malaysia.

\section{Abstract}

This research examines the innovation as a mediator on Access to Finance (AF) and Business Performance (BP) of women entrepreneurs in Nigeria using Innovation (I) as a mediator in order to improve the performance of Women which at the long-run contribute positively towards the increase of Nigeria GDP. Data required for the study was collected from the Women Micro, Small and Medium Enterprises (MSME's) operating in the North-Western Nigeria using a survey design using a systematic random and stratified disproportionate sampling. A designed questionnaire has been distributed across the target population of 576 through self-administration. In order to evaluation the proposed data, the study has adopted the Partial Least Squares-Structural Equation Modelling (PLS-SEM). The findings revealed that AF and Innovation are important strategic for the performance of women MSMEs in Nigeria. The findings also revealed that women MSME performance depends on the degree of AF of the business performance. However, innovation was found to mediate on Access to Finance and Business Performance of Women Entrepreneurs. The results of the study will provide important insights to women owner/managers of MSMEs, policy makers and researchers to further understand the influence of AF and Innovation on women MSME performance. Women MSMEs should also be encouraged to improve their AF and I which may increase their performances.

Keywords: Access to Finance, Innovation, Women Business Performance and Micro Small and Medium Enterprises (MSMEs)

\section{INTRODUCTION}

The importance of MSMEs in influencing the economic growth and development of a country is recognized all the over the world as their performance is unanticipated (Ibrahim \& Rosli, 2016; Ali, Hilman \& Gorondutse, 2017; Gorondutse, Ali, Abubakar \& Naalah, 2017).

The level of SMEs contribution to the Nation's Gross Domestic Product (GDP) and employment which indicate their low performance (Naala, Nordin \& Omar, 2017). This lead many researchers and 
practitioners to give so much attention to their significant contributions to the economic growth and the development in both developing and developed nations (Gorondutse, Ibrahim, Abdullwahab, \& Naalah, 2018; Naala Nordin \& Omar, 2017; Naala, 2016; Eniola, 2014).

Women entrepreneurs, particularly in developing countries, have difficulty in accessing financial facilities for entrepreneurial activity and this lead to low business performance compared to men counterparts, While, the participation of women in informal sector of the economy is higher than males (Ike, 2017; Momoh, 2013). Women entrepreneurs in developing countries, Nigeria inclusive, are particularly saddled with certain peculiarities that hinder their ability to have access to finance within the society. Their cultural practice characterizes these impediments, for example, early marriage, male influence in every sphere, and low formal education they regard as an obstruction to women because the husbands are too busy to help at home even when the need arises. Furthermore, the male does not allow their wives to go out because of the strong religion and culture fact that limit women movement only with their husbands (Idris \& Agbim, 2015).

In other words, women activities specifically in business empower them economically and enable them to contribute to the general development of the nation. Yet, women in the most parts of the developing world (including Nigeria) continue to face various forms of discriminations, which limit their opportunities to develop to their full potentials and they also face some difficulties in pursuit of enterprise success (Koko, Maishanu \& Hassan, 2017; Abubakar, 2013). Women entrepreneurs are indeed innovative by nature in an attempt to create economic value and satisfy family needs, they create businesses and exhibit entrepreneurial acumen. Indeed their contributions to the sustenance of families and economy of their respective communities are enormous. Furthermore, Ogujiuba, Fadila and Stiegler (2013) Koko et al. (2017) and Koko (2014) express the needs and relevance of encouraging women's access to finance as well as improving economic diversification and growth. The authors also stated that the empowerment of women could encourage and inspire development in a community.

The current study used innovation as a mediator to probe the effects of access to finance on business performance of women entrepreneurs. More so, it is significant to note that it will be very difficult to evaluate the link between access to finance and business performance of women entrepreneurs without analyzing the mediating variable of innovation, and how they affect each other under what? Condition of indirect effects (Baron \& Kenny, 1986; Hayes, 2009). Therefore, based on the literature review, this study have intends to investigate if innovation mediates between access to finance on business performance of women entrepreneurs in the North-Western Nigeria.

The paper is classified into five segments, the introductory part, literature review, while the third and fourth segments include the methodology as well as the result and discussions, respectively. Lastly, the paper provided a conclusion.

\section{LITERATURE REVIEW}

Lee, Sameen, and Cowling (2015) studied the influence of access to finance and financial crisis of innovative SMEs using a sample of over 10,000 UK SMEs employers. Survey data were collected using questionnaires and regression analysis was conducted for data analysis. Finding indicated that low access to finance have restricted the growth of innovative firms. The use of limited information on the quality of both innovation and firm was highlighted as the limitation of the study. Likewise, 
Lee, Dedahanov \& Rhee (2015) studied the role of innovation performance on financial performance. The data was collected from 352 organisations in South Korea using hierarchical regression analysis. The outcomes shown a positive significant influence on the relationship between the innovation performance and financial performance.

Lu, Zhu and Bao (2015) investigated the High-performance human resource management and firm performance on the mediating role of innovation in China. A sample of 150 pre-survey Chinese manufacturing industries in Beijing, Changchun, Harbin, Shanghai, Shenzhen, and other cities using questionnaire and PLS-SEM for data analysis. The results revealed that innovation has a significant positive impact of high-performance on HRM and firm performance. The researchers suggested future study to expand innovation scope as a variable to various enterprises. Additionally Camisón and Villar López (2010) examined the mediating role of innovation on the relationship between manufacturing flexibility and firm performance with a sample of 159 Spanish firms using questionnaires and personal interviews for data collection while PLS-SEM for data analysis. Findings revealed that the mediating variable have a significantly positive influence on the organizational performance.

Helm, Mauroner and Dowling (2010) exploded entrepreneurial orientation and spin-off venture performance and the mediating role of Innovation using questionnaire for data collection with a sample of 350 entrepreneurs in high technology spin-off companies in Germany with structural equation modelling for data analysis Findings revealed that innovation have a significance influences on the entrepreneurial orientation and new venture performance. Further studies should consider the use of multi-source data.

Sharma, Davcik and Pillai (2016) investigated the role of mediating product innovation in influence Research, Development expenditure of brand equity on marketing performance with a sample of 10,282 data of Bureau van Dijk Electronic and ACNielsen Italy's report on household`s financial statement of food purchase database using regression for data analysis. Findings showed a Research, Development expenditure and Brand Equity showed a significance positive relationship on marketing performance of product innovation. Recommend future study to use product innovation as a moderator in influencing marketing performance.

Therefore, on the ground of the above literature reviewed this present study suggests the following hypotheses:

$\mathrm{H}_{1}$ Access to finance has a significance positive effect on business performance of women entrepreneurs in the North-Western Nigeria.

$\mathrm{H}_{2}$ Innovation has a significance positive effect on business performance of women entrepreneurs in the North-Western Nigeria.

$\mathrm{H}_{3}$ : Innovation mediates the effect of Access to finance (AF) on business performance of women entrepreneurs in the North-Western Nigeria

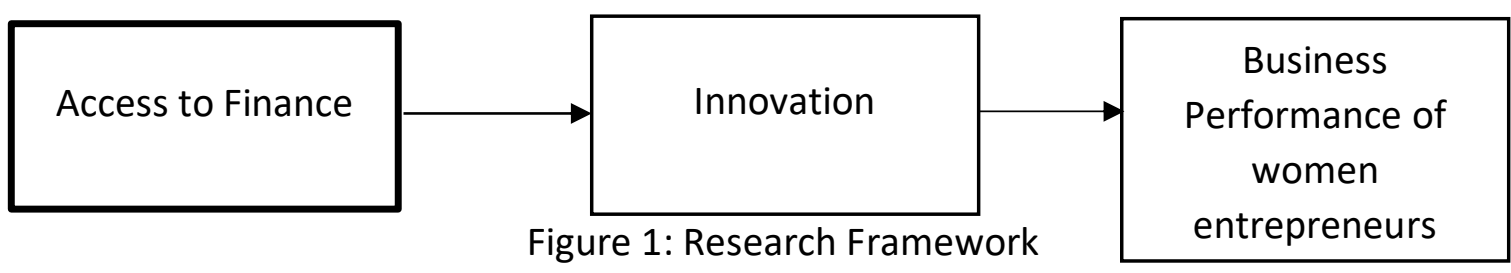


This study employed the Resource-Based Theory (RBT) and Pecking Order Theory for enhancing and supporting the framework. The RBT encapsulates the focus of the study by taking into consideration the relations among the variables. In this study, the Resource-Based Theory (RBT) is adapted to explain the effect between dependent variable, and mediating variable business performance of women entrepreneurs as the dependent variable and lastly the mediating role of innovation as it exploited the strengths and weaknesses of the businesses, which may leads to outperformance on businesses. In this study, access to finance is selected as the independent variables. While the development of the Pecking Order Theory was motivated by lack of asymmetric information regarding financial markets as well as external financing transaction costs (Vasilou, Eriotis \& Daskalakis, 2009). The theory affirms that managers are often the sole custodian of a significant part of the information related to the conditions and prospects of their firms, compared to the external investors from outside. The focus of the study is primarily on how businesses generate and achieve their performances. The Pecking Order Theory suggests a hierarchical order in choosing the available financing source. Thus, Pecking Order Theory (POT) suggested that those women entrepreneurs facing problem regarding shortage of fund will seek to obtain fund through friends, relatives, families, retained profits to preserve assets, debt and agencies to improve their performance.

In conformity to the RBT, innovation is business's resource, which is likely to give a sustainable and outstanding performance to the business, For a business organisation to have innovation, it must encourage the introduction of new ideas, creativity, testing and creative response to situations that will result in new products and new ways of doing things (Halim et al., 2014), while innovation is the ability and strength of a business enterprise to initiate new measurement of actualizing the new products and the ideas to produce (Covin \& Mille, 2014).

\section{METHODOLOGY}

The present study examines whether innovation mediates the impacts of access to finance on business performance of women entrepreneurs in the North-Western Nigeria. The population consists of owners/managers of MSMEs in the North-Western Nigeria.

Employing disproportionate random sampling to determine the amount of sample drawn from the population of MSMEs in each state, a simple random technique of selecting the sample from three states was used (Kano, Kaduna and Sokoto States) which data were finally collected for analysis of this study. Questionnaires were administered to 576 owners/managers of MSMEs who are registered member of Nigeria Association of Micro Small and Medium Enterprises (MSME). only, 452 (78.5\%) were returned completely answered while 428 (74.3\%) were suitable for final analysis due to removal of ambiguous responses and outliers. Thereafter, SPSS version 25 and the Smart-PLS SEM 3 were used for data analysis (Hair et al., 2017).

The research framework comprises of 3 constructs and multiple items were used to measure each of the variable. The latent construct were measured with uni-dimensional and reflective items and all the constructs were scored on 5-point Likert scale of (1) Agree (2) Strongly Agree (3) Disagree (4) Strongly Disagree (5) Neither Agree/ nor Disagree. The study uses seven items adopted from Suliyanto and Rahab (2012) to measure BP eight items were used for access to finance adapted from 
Bouri et al. (2011) and Innovation 6 with items adapted from (Huhtala, Sihvonen, Frösén, Jaakkola, \& Tikkanen, 2014: Vorhies \& Morgan 2005).

Common method bias test were conducted because of self-administered questionnaires cross-sectional survey approach (Podsakoff, MacKenzie, Lee, \& Podsakoff, 2003). Additionally, Harman's single factor test was adapted to study CMV which assumes that, if an amount of CV considerably exist in any single factor or one overall factor that would account for more than half of the covariance in the independent and dependent variables (Podsakoff \& Organ, 1986). All indicators in the current study were subjected to principal component factor analysis in accordance with Podsakoff and Organ (1986). And no single factor in this study has the majority of covariance in the independent and dependent variables (Podsakoff, MacKenzie, \& Podsakoff, 2012), suggesting the unimportance of $\mathrm{CMB}$ that may likely inflate the link between the variables measured in the current study.

\section{RESULT AND DISCUSSION}

This study conducted reliability test using values from composite reliability and the values from these measures for each construct has exceeded the recommended figure of 0.70 (Hair et al., 2014) as described in Table 1. The results confirmed that all the reliability was met. As regards the validity, the discriminant validity of cross loadings which is referred to as the item-level (Henseler, Ringle, \& Sarstedt, 2016), indicated that item loading on the variable its measures is greater than it loadings on other variable in the model (Chin, 1998). The average variance extracted for all the variables have exceeded the recommended values of 0.50 as revealed in Table 1, thus convergent validity was attained for this study (Fornell \& Larcker, 1981; Hair, \& Lukas, 2014). However, for discriminant validity and the squared root of AVEs of each variable is greater than inter-construct correlation estimates (Hair, Hult, Ringle, Sarstedt, \& Thiele, 2017). This is shown in Table 2. Further confirmation of mediation test and direct relationship after minimum values was achieved as indicated in Table 4 and 5. These indicated that all the constructs of the study attain acceptable level of (Hair et al., 2016). 
INTERNATIONAL JOURNAL OF ACADEMIC RESEARCH IN BUSINESS AND SOCIAL SCIENCES

Vol. 9, No. 3, March, 2019, E-ISSN: 222 2-6990 @ 2019 HRMARS

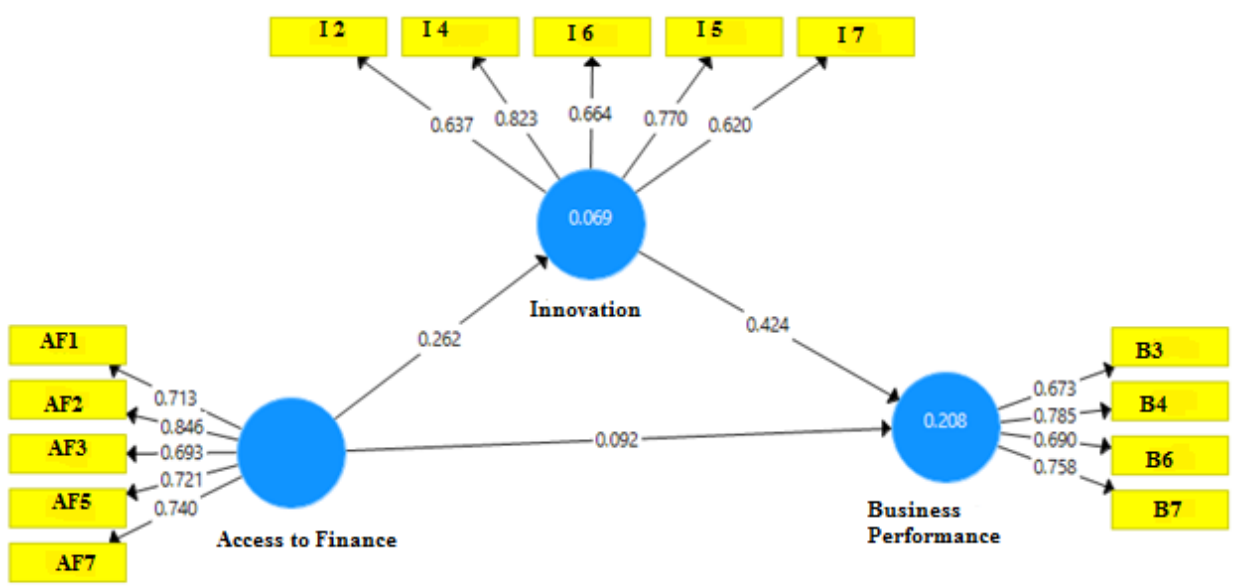

Fig. 2 PLS Algorithm

Table 1: Indicator Loadings and Internal Consistency Reliability

\begin{tabular}{|c|c|c|c|c|c|}
\hline Variables & Indicators & Standardized Loadings & Composite Reliability & AVE & Item(s) deleted \\
\hline $\begin{array}{l}\text { Business } \\
\text { Perf. }\end{array}$ & BP3 & 0.673 & 0.818 & 0.530 & \multirow[t]{4}{*}{ BP1, BP2, BP5 } \\
\hline & BP4 & 0.785 & & & \\
\hline & BP6 & 0.690 & & & \\
\hline & BP7 & 0.758 & & & \\
\hline \multirow[t]{5}{*}{ Innovation. } & 12 & 0.637 & 0.832 & 0.500 & 11 \\
\hline & 13 & 0.620 & & & \\
\hline & 14 & 0.823 & & & \\
\hline & 15 & 0.770 & & & \\
\hline & 16 & 0.664 & & & \\
\hline \multirow[t]{5}{*}{$\begin{array}{l}\text { Access to } \\
\text { Finance }\end{array}$} & AF1 & 0.713 & 0.861 & 0.554 & AF4, AF6 \\
\hline & AF2 & 0.846 & & & \\
\hline & AF3 & 0.693 & & & \\
\hline & AF5 & 0.721 & & & \\
\hline & AF7 & 0.740 & & & \\
\hline
\end{tabular}

Table 2: Discriminant Validity Fornell-Larcker Criterion 
INTERNATIONAL JOURNAL OF ACADEMIC RESEARCH IN BUSINESS AND SOCIAL SCIENCES Vol. 9, No. 3, March, 2019, E-ISSN: 222 2-6990 @ 2019 HRMARS

\begin{tabular}{|l|l|l|l|}
\hline Latent Variables & $\mathrm{BP}$ & $\mathrm{I}$ & $\mathrm{AF}$ \\
\hline $\mathrm{BP}$ & $\mathbf{0 . 7 2 8}$ & & \\
\hline $\mathrm{I}$ & 0.448 & $\mathbf{0 . 7 0 7}$ & \\
\hline $\mathrm{AF}$ & 0.203 & 0.262 & $\mathbf{0 . 7 4 4}$ \\
\hline
\end{tabular}

Table 3 Cross Loadings

\begin{tabular}{|l|l|l|l|}
\hline Latent Variables & Business Performance & Innovation & Access to Finance \\
\hline BP3 & $\mathbf{0 . 6 7 3}$ & 0.225 & 0.210 \\
\hline BP4 & $\mathbf{0 . 7 8 5}$ & 0.399 & 0.206 \\
\hline BP6 & $\mathbf{0 . 6 9 0}$ & 0.245 & 0.142 \\
\hline BP7 & $\mathbf{0 . 7 5 8}$ & 0.382 & 0.049 \\
\hline I2 & 0.194 & $\mathbf{0 . 6 3 7}$ & 0.121 \\
\hline I3 & 0.268 & $\mathbf{0 . 6 2 0}$ & 0.065 \\
\hline I4 & 0.421 & $\mathbf{0 . 8 2 3}$ & 0.242 \\
\hline I5 & 0.364 & $\mathbf{0 . 7 7 0}$ & 0.263 \\
\hline I6 & 0.262 & $\mathbf{0 . 6 6 4}$ & 0.160 \\
\hline AF1 & 0.147 & 0.171 & $\mathbf{0 . 7 1 3}$ \\
\hline AF2 & 0.214 & 0.214 & $\mathbf{0 . 8 4 6}$ \\
\hline AF3 & 0.066 & 0.136 & $\mathbf{0 . 6 9 3}$ \\
\hline AF5 & 0.057 & 0.197 & $\mathbf{0 . 7 2 1}$ \\
\hline AF7 & 0.199 & 0.230 & $\mathbf{0 . 7 4 0}$ \\
\hline
\end{tabular}

The outcome of the data analysis using Smart-PLS SEM software is shown in figure 2. This paper measured predictive relevance of the model and R-squared values based on the PLS-SEM result of $20.8 \%$ and $6.9 \%$ of the total variance explained on the independent variable to dependent construct and independent variable to mediator respectively. This suggests that the AF explained $20.8 \%$ of variance in MSMEs performance. Cohen (1988) Classified three categories of R-square, 0.02 weak, 0.26 substantial and 0.13 moderate thus based on the R-squared of this study it moderate and weak respectively. 


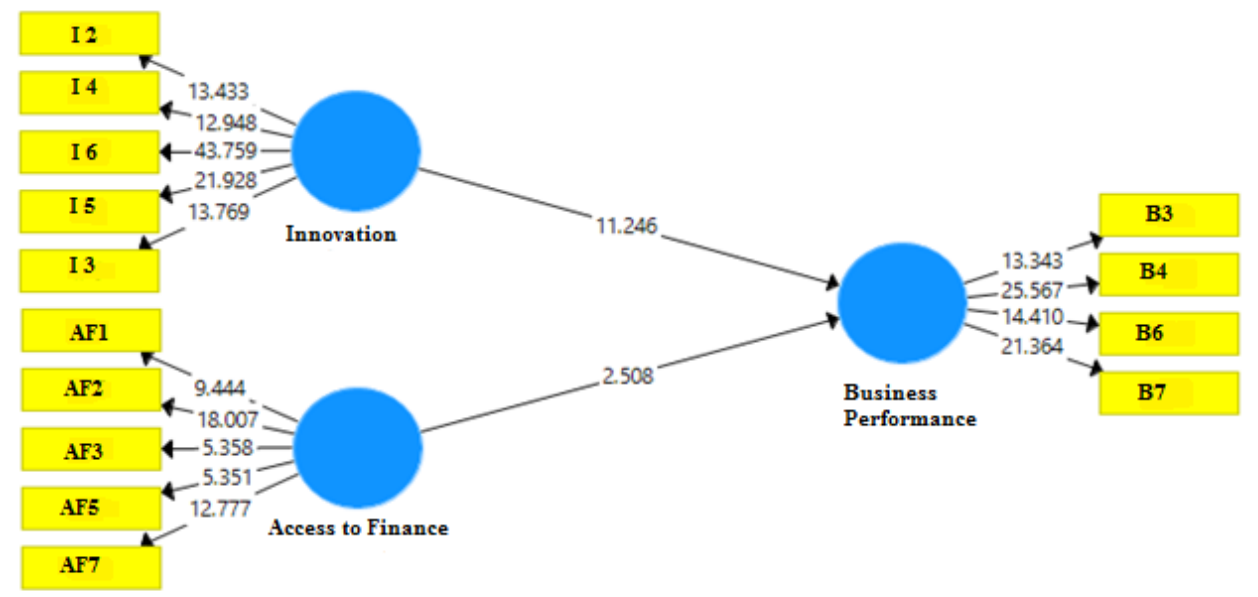

Figure 3: Direct Relationship between the variables.

The testing of hypotheses was conducted using Smart-PLS SEM software to determine the direct relationship and the interaction effect $(\mathrm{H} 1-\mathrm{H} 3)$. Statistical model for direct relationship displays the links between AF, I independent latent variables and Business Performance of women entrepreneurs dependent latent variable as shown in figure 3. Table 4 illustrations the outcomes of the direct relationship between independent and dependent variable.

Table 4: Hypotheses Testing of Direct Relationship

\begin{tabular}{|l|l|l|l|l|l|l|}
\hline Hypothesis & Path & Beta & STDEV & t-value & p-value & Remarks \\
\hline $\mathrm{H}_{1}$ & AF $->$ BP & 0.418 & 0.037 & 11.246 & 0.000 & Accepted \\
\hline $\mathrm{H}_{2}$ & I -> BP & 0.113 & 0.045 & 2.508 & 0.000 & Accepted \\
\hline
\end{tabular}

The findings as shown in Table 4 revealed that Access to finance on business Performance of women entrepreneurs has a significant positive effect and support with $\mathrm{H}_{1}(\beta=0.418)$ and $\mathrm{t}$ value $(t$ $=11.246$ ), and this concurs with the past studies (Sajuyigbe, 2017; Harelimana, 2017; Fowowe, 2017). Similarly, the direct relation between innovation on business performance of women entrepreneurs was also tested and findings shows a positive significant effect among the variables Innovation on Business performance of women entrepreneurs with $\mathrm{H}_{2}(\beta=0.113)$ and $t$ value $(t=2.508)$. Access to finance will give women entrepreneurs the ability to eliminate financial gap faced by MSMEs through direct government interventions of credit guarantee which will increase their performance and contribution to GDP. Although it is believe that the size of the firm has a significant factor in accessing finance and it is suggested that small businesses to form association by coming together to form bigger businesses to attract better source of finance and to eliminate financial gap faced by MSMEs 
through a direct government intervention of credit guarantee. Therefore, MSMEs in Nigeria should encourage individuals and government support to Nigerian MSMEs. Although the current performance and the desired performance which could lead to better business performance.

The outcome of the study reveal that majority of the respondents are from the micro small businesses. Women owner/managers are not investing much in the medium enterprises because of the financial restriction and barriers because the finding seems to suggest that credits from banks to traders have both positive and negative influence on MSMEs. This shows that MSMEs that adopt business vision will generate more profit that yield high retained earnings. Drawing upon the notion that support the understanding of several studies that access funding depending on the MSMEs' strategic activities or vision in Consistent with the POT, business outcome depends on the bundle of business resources.

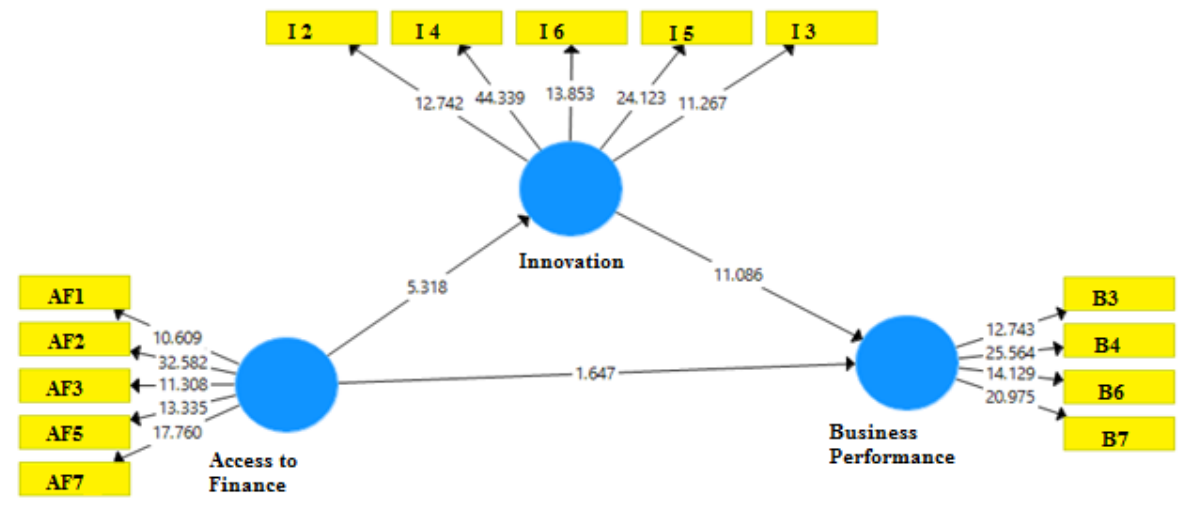

Fig. 4: Mediating effect

Table 5: Illustrate the summary of mediation relationship

\begin{tabular}{|l|c|c|c|c|c|c|}
\hline Hypothesis & Path & Beta & STDEV & t-value & p-value & Remarks \\
\hline $\mathrm{H}_{3}$ & AF $>$ I $>$ - B P & 0.111 & 0.024 & 4.548 & 0.000 & Accepted \\
\hline
\end{tabular}

The structural model that shows the mediating relationship of innovation on the effect of AF and $\mathrm{BP}$ was demonstrated in figure 4. Table 5 explain the indirect relationship among the two variables AF and Innovation with a $(\beta=0.111)$ and $t$ value $(t=4.548)$.

The finding shows a mediated relationship on the impact of access to finance on business performance of women entrepreneurs where innovation serves as the channel of enhancing business performance of women entrepreneurs. Nigerian women MSMEs in (Kaduna, Kano and Sokoto States) that have access to financing to generate substantial cash flow of both internal and external financial 
resources are assumed to have better strategic activities and also more likely to employ more staff, and have investments plans, high sales volume and profit than the others that lack access to finance.

The finding helps in filling the gap of literature with regard to the effect/role of innovation as a mediator on AF and business performance of women entrepreneurs, specifically in Nigeria MSMEs context. The effect is assumed to mediate if independent/predictor variable has effects on the dependent/outcome variable through the mediating variable (Baron \& Kenny, 1986). Therefore, the results show that $A F$ has an effect on the mediator variable of innovation, and this in turn influences the dependent variable of business performance (Hair et al., 2016).

\section{CONCLUSIONS}

In conclusion the performance of women MSMEs will remain an important issues in Nigeria for employees of, academician's, researchers, political leaders, managers, and community at large. It is believed that the women MSMEs performance will provide a rich backdrop of room for improvement on the GDP if the government provide the right access to finance in generating substantial cash flow of both internal and external financial resources which is assumed to give then better strategic activities in employing different innovative technology and at the same more likely to employ more staff, and have many investments plans, high sales volume and profit than the others that lack access to finance. This study suggests other researchers to expand the scope by considering other variables and looking at other zones or Nigeria as a whole.

\section{REFERENCES}

Abubakar, K. M. (2013). Capital Access Strategies and Enterprise Growth: A Study of Selected Indigenous Women Entrepreneurs in Sokoto Metropolis, Nigeria. Sokoto Journal of Management Studies, 4(1), 25-38.

Baron, R. M., \& Kenny, D. A. (1986). The moderator-mediator variable distinction in social psychological research: Conceptual, strategic, and statistical considerations. Journal of personality and social psychology, 51(6), 1173.

Bouri, A., Breij, M., Diop, M., Kempner, R., Klinger, B., \& Stevenson, K. (2011). Report on support to SMEs in developing countries through financial intermediaries. Dalberg, November.

Camisón, C., \& Villar-López, A. (2014). Organizational innovation as an enabler of technological innovation capabilities and firm performance. Journal of business research, 67(1), 2891-2902.

Chin, W. W. (1998). The partial least squares approach to structural equation modeling. Modern methods for business research, 295(2), 295-336.

Cohen, J. (1988). Statistical power analysis for the behavioural sciences.

Covin, J. G., \& Miller, D. (2014). International entrepreneurial orientation: Conceptual considerations, research themes, measurement issues, and future research directions. Entrepreneurship Theory and Practice, 38(1), 11-44.

Fornell, C. and Larcker, D.F. (1981), "Evaluating structural equation models with unobservable variables and measurement error", Journal of Marketing Research, Vol. 18 No. 1, pp. 39- 50.

Fornell, C. and Larcker, D.F. (1981), "Evaluating structural equation models with unobservable variables and measurement error", Journal of Marketing Research, Vol. 18 No. 1, pp. 39- 50. 
INTERNATIONAL JOURNAL OF ACADEMIC RESEARCH IN BUSINESS AND SOCIAL SCIENCES

Vol. 9, No. 3, March, 2019, E-ISSN: 222 2-6990 @ 2019 HRMARS

Fowowe, B. (2017). Access to finance and firm performance: Evidence from African countries. Review of Development Finance, 7(1), 6-17.

Gorondutse, A. H., Ali, R. A., Abubakar, A., \& Naalah, M. N. I. (2017). The effect of working capital management on SMEs profitability in Malaysia. Polish Journal of Management Studies, 16.

Gorondutse, A.H., Ibrahim, G., Abdullwahab, H.I. and Naalah, M.N.I., 2018. Founder's Syndrome and Firm Performance of Small and Medium Scale Enterprises in Nigeria. Journal of Health Management and Informatics, 5(1), pp.1-8.

Hair, J., Hollingsworth, C. L., Randolph, A. B., \& Chong, A. Y. L. (2017). An updated and expanded assessment of PLS-SEM in information systems research. Industrial Management \& Data Systems, 117(3), 442-458.

Aliyu, R. M., Ahmad, T, S., and Nordin, N. (2018) The effects of Market Orientation and Training on business performance of women: The Mediating role of Innovation. International Journal of Social Science and Economic Research, 3(11), 6451-6467.

Halim, H. A., Ahmad, N. H., Ramayah, T., \& Hanifah, H. (2014). The growth of innovative performance among SMEs: Leveraging on organisational culture and innovative human capital. Journal of Small Business and Entrepreneurship Development, 2(1), 107-125.

Harelimana, J. B. (2017). Role of Access to Finance for the Performance of Small and Medium Enterprises in Muhoza Sector, Rwanda. Account and Financial Management Journal, 2(01), 559-567.

Hayes, A. F. (2009). Beyond Baron and Kenny: Statistical mediation analysis in the new millennium. Communication monographs, 76(4), 408-420.

Helm, R., Mauroner, O., \& Dowling, M. (2010). Innovation as mediator between entrepreneurial orientation and spin-off venture performance. International Journal of Entrepreneurship and Small Business, 11(4), 472-491.

Henseler, J., Ringle, C. M., \& Sarstedt, M. (2016). Testing measurement invariance of composites using partial least squares. International Marketing Review, 33(3), 405-431.

Huhtala, J. P., Sihvonen, A., Frösén, J., Jaakkola, M., \& Tikkanen, H. (2014). Market orientation, innovation capability and business performance: Insights from the global financial crisis. Baltic Journal of Management, 9(2), 134-152.

Ibrahim, N., Mahmood, R., \& Bakar, M. (2016). Linking strategic improvisation and entrepreneurial self-efficacy to corporate entrepreneurship in Nigerian higher education institutions (HEIs). Management Science Letters, 6(12), 742-752.

Idris, A. J., \& Agbim, K. C. (2015). Micro-credit as a strategy for poverty alleviation among women entrepreneurs in Nasarawa State, Nigeria. Journal of Business Studies Quarterly, 6(3), 122.

Ike, P. C. (2013). Analysis of impact of microfinance services on business performance of small scale women entrepreneurs in Enugu State, Nigeria. Asian Journal of Agriculture and Rural Development, 3(6), 424.

Koko, M. A, Maishanu, M. M, \& Hassan, A. (2017). Women entrepreneurs' accessibility to growth capital and socio-economic development in Sokoto State, Nigerian. IOSR Journal of business \& Management,19(5) 69-75

Koko, M. A. (2014). Enterprise Characteristics and Accessibility to Growth Capital: Study of Indigenous Women's Enterprises in Sokoto, Nigeria. World, 4(2). 
Lee, D. H., Dedahanov, A. T., \& Rhee, J. (2015). Moderating role of external networks and mediating effect of innovation performance on the relationship between technology orientation and firm performance. Asian Journal of Technology Innovation, 23(3), 321-334.

Lee, N., Sameen, H., \& Cowling, M. (2015). Access to finance for innovative SMEs since the financial crisis. Research policy, 44(2), 370-380.

Lu, K., Zhu, J., \& Bao, H. (2015). High-performance human resource management and firm performance: The mediating role of innovation in China. Industrial Management \& Data Systems, 115(2), 353-382.

Momoh, I. (2013). Creating a database for Nigerian MSMEs. Business Day.

Naala, M. I. N., Nordin, N., \& Omar, W. A. W. (2017). Innovation Capability and Firm Performance Relationship: a Study of Pls-Structural Equation Modeling (Pls-Sem). International Journal of Organisation \& Business Excellence, 2(1), 39-50.

Naala, M. N. I. (2016). Moderating and mediating roles of human capital and competitive advantage on entrepreneurial orientation, social network and performance of SMEs in Nigeria (Doctoral Dissertation). Universiti Utara Malaysia.

Ogujiuba K, Fadila\&Stiegler (2013). "Challenges of Microfinance Access in Nigeria: Implication for Entrepreneurship Development". Mediterranean Journal of Social Science. 4 (6).

Podsakoff, P. M., \& Organ, D. W. (1986). Self-reports in organizational research: Problems and prospects. Journal of management, 12(4), 531-544.

Podsakoff, P. M., MacKenzie, S. B., \& Podsakoff, N. P. (2012). Sources of method bias in social science research and recommendations on how to control it. Annual review of psychology, 63, 539569.

Podsakoff, P. M., MacKenzie, S. B., Lee, J. Y., \& Podsakoff, N. P. (2003). Common method biases in behavioral research: A critical review of the literature and recommended remedies. Journal of applied psychology, 88(5), 879.

Sajuyigbe, A. S. (2017). influence of financial inclusion and social inclusion on the performance of women-owned businesses in Lagos State, Nigeria. Scholedge International Journal of Management \& Development, 4(3), 18-27.

Sharma, P., Davcik, N. S., \& Pillai, K. G. (2016). Product innovation as a mediator in the impact of R\&D expenditure and brand equity on marketing performance. Journal of Business Research, 69(12), 5662-5669.

Suliyanto, S., \& Rahab, R. (2012). The role of market orientation and learning orientation in improving innovativeness and performance of small and medium enterprises. Asian Social Science, 8(1), 134.

Vasiliou, D., Eriotis, N., \& Daskalakis, N. (2009). Testing the pecking order theory: the importance of methodology. Qualitative Research in Financial Markets, 1(2), 85-96.

Vorhies, D. W., \& Morgan, N. A. (2005). Benchmarking marketing capabilities for sustainable competitive advantage. Journal of marketing, 69(1), 80-94. 